ELORE (ISSN 1456-3010), vol. $14-1 / 2007$.

Julkaisija: Suomen Kansantietouden Tutkijain Seura ry.

[http://www.elore.fi/arkisto/1_07/aar1_07.pdf]

\title{
Tilallista kerrontaA Turun linNassa
}

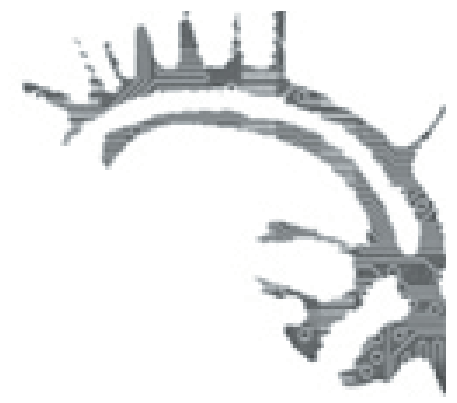

\section{$\underline{\text { Petja Aarnipuu }}$}

Turun linna, niin kuin kulttuuriperintökohteet useinkin, on samanaikaisesti hyvin vanha ja varsin nuori. Sitä on alettu rakentaa vuoden 1300 tuntumassa, mutta toisaalta sen 1900-luvulla restauroituja seiniä ja pihoja puolustetaan vedeltä, tulelta ja muilta vihollisilta uuden vuosituhannen teknologialla. Kulttuuriperintö muodostuu aineellisuuksien ja aineettomuuksien, ajallisten jatkuvuuksien ja katkosten, toden ja fiktion jäsentymisestä merkityksellisiksi kokonaisuuksiksi. Kulttuuriperintö - edes kivisen linnan tapauksessa - ei vain koostu vuosien ja vuosisatojen seuratessa toisiaan. Se on tietoisten valintojen tulosta.

Tässä artikkelissa teen ensin aineellisesta aineetonta: vien kivilinnan sellaiselle abstraktiotasolle, että voin tarkastella sitä monumentaalisena eli muistoa säilyttävänä kerrontana. Aloitan tilan ja kerronnan käsitteistä sellaisina, kuin minä ne näen, ja jatkan kuvaamalla ongelmakenttää, Turun linnan restauroituja arkkitehtonisia tiloja, jotka historiallisesta todellisuudesta katsoen voidaan tulkita jopa anakronistisiksi. Tarjoan tulkinnalliseksi avaimeksi mimesis-mallia, jota käytän avatessani Turun linnan kompleksisia, kerronnallisesti aktuaalistuvia tila- ja aikaulottuvuuksia. Lopuksi paneudun toisensuuntaiseen prosessiin esittämällä, miten Turun linnan tonttu-ukko materialisoitui satukirjan sivuilta oman opastetun kierroksen ja sisustetun kamarin haltijaksi ja unohdetun muiston merkiksi.

\section{NARRATIIVINEN TILA}

Arkipuheessa paikka on kiintopiste tilan avaruudessa, ja toisaalta paikka jakautuu tiloihin, erityisesti jos kysymyksessä on rakennus. Edelleen tiloissa saattaa olla numeroituja paikkoja, mutta monessa paikassa voi usein asettua sinne missä on tilaa. Akateemisissa keskusteluissa tilan ja paikan konseptit ovat olleet esimerkiksi folkloristien ja kulttuurimaantieteilijöiden yhteisen kiinnostuksen kohteena - myös oma ymmärrykseni tilasta sijoittuu tälle kulttuurintutkimukselliselle yhteismaalle. Oman tutkimukseni käsitteellisenä lähtökohtana on Michel de Certeaun 1974 tiivistämä ja sittemmin klassikoksi muodostunut määritelmä, jonka mukaan "tila on käytössä oleva paikka”" (de Certeau 2002, 117; käännös Saarikangas 2002, 69). De Certeaun analyysissä paikka kuvaa asioiden sijaintia samanaikaisesti ja suhteessa toisiin paikkoihin: paikat 
voidaan sijoittaa kartalle. Siinä missä paikka viittaa jonkinasteiseen pysyvyyteen tila muodostuu jossakin hetkessä erilaisten tekijöiden ja toiminnan tuloksena.

Omassa tutkimuksessani tila on pääkäsite, jonka keskeiset komponentit ovat paikka, aika ja toiminta. Tilat ovat avaruudellisia sosiaalisen toiminnan näyttämöjä. (Ks. Saarikangas 2002, 49.) Turun linnan kaltaisessa monumentaalisessa rakennusperintökohteessa paikan tilallistumista ohjaavat voimakkaasti ajan representaatiot sen lisäksi, että kunkin kävijän kannalta linnasta tulee elettyä tilaa suhteessa hänen omaan elämänhistoriaansa. Nykykävijän kokemat ja käynnillään aktuaalistamat tilat Turun linnassa ovat monumentaalisia tiloja, jotka on Henri Lefebvren sanoin rakennettu sekä synnyttämään kysymyksiä että vastaamaan niihin. Lefebvren mukaan monumentaalinen tila edustaa sen rakentanutta yhteisöä ja tarjoaa "kollektiivisen peilin", josta yhteisön jäsenet näkevät yhteisöllisen kuvansa - monumentaalisessa tilassa heidät suorastaan pakotetaan siihen. (Lefebvre 1991, 220.)

Kun kyseessä on Turun linnan kaltainen kansallinen kulttuuriperintökohde, onkin selvää, että tilan merkityksellistäminen tapahtuu myös yhteisöllisesti, hierarkkisesti yksilön yläpuolella. Kulttuuriperintö-tematiikan kannalta on tärkeää tietää ja ymmärtää, että Turun linnan huonetiloja on vuosisatojen kuluessa sekä hävitetty että kutsuttu jälleen esiin. Tutkimukseni lähtökohtana ovat Turun linnassa erityisesti 1900-luvun puolenvälin suurten restaurointien yhteydessä tehdyt, nykyistä kulttuuriperintöämme muovanneet valinnat.

Michel de Certeaun ja Henri Lefebvren tilan määritelmissä tila syntyy ja tila hallitsee, mutta tilan tekijät - ajateltiinpa heitä de certeaulaisina toimijoina tai lefebvreläisinä vallankäyttäjinä - jäävät taka-alalle. Tästä syystä tilan käsitteellistäminen ei vielä anna riittävästi avaimia omiin tutkimuskysymyksiini, vaan haluan jatkaa Turun linnan tulkitsemista kerronnallisuuden valossa. Minua kiinnostavat rakennettujen tilojen tuotetut merkityssisällöt, eli mitä tilassa ja tilalla kerrotaan. Siksi etsin ajan ja paikan tulkintoja - ja sitä kautta tilan luomisen prosesseja - sekä linnan restauroiduista rakenteista että katoavaisemmista teksteistä: kirjallisista tutkimuksista, opastetuilta kierroksilta, opaskirjoista ja esitteistä. Analysoin aineellista kulttuuriperintöä suhtautumalla pälinnaan ikään kuin se olisi kerrottu kertomus: näin pyrin avaamaan uusia, folkloristiikan tiedonintresseistä katsoen relevantteja näkökulmia rakennettuun kulttuuriperintöön. Tilallisuus muodostuu tässä yhtäältä ajallisesta ja paikallisesta ympäristöstä, joka aktuaalistuu esimerkiksi opastettujen kierrosten yhteydessä, oppaiden tehdessä arkkitehtonisesta tilasta merkityksellistä tilaa nimenomaan kerronnallisesti. Toisaalta tilallisuus on kerronnan keino ja kieli, jolloin kertojina ovat restauroijat.

\section{0-LUVUN KESKIAIKAISESTA LINNASTA 1900-LUVUN KESKIAIKAISEKSI LINNAKSI}

Nykyajan Turun linna on jaettu kahteen funktionaaliseen pääosaan. Esilinna on museo, jossa voi tutustua sinne sisustettuihin interiööreihin eri ajoilta. Suurimmalla osalla näistä interiööreistä ei ole suoraa yhteyttä juuri Turun linnan historiaan, vaan niiden 
avulla esitellään yleisemmin eri aikojen herrasväen sisustustapoja ja esineistöä (ks. Appelgren 2000). Museotoiminta Turun linnassa alkoi esilinnasta 1880-luvulla. Päälinna sen sijaan restauroitiin 1940-luvulla alkaneissa, 1960-luvulle ja edelleen 1990-luvulle jatkuneissa suururakoissa rakennusmonumentiksi. Siellä on toki myös näyttelytiloja ja vaihtuvia näyttelyjä, mutta aivan erityisesti päälinnassa voi tutustua Turun linnan omaan historiaan. Tilat on restauroitu sellaisiksi kuin ne ovat jossain ajassa olleet. C. J. Gardbergin 1961 laaditussa opaskirjassa käyttämän ilmauksen mukaan ne on "entisöity alkuperäiseen asuunsa" (Gardberg 1961b, 7).

Niin kuin vanhoissa rakennuksissa yleensä, Turun linnan vanhassa pääosassa on näkyvissä useita rinnakkaisia ajallisuuksia. Linnaa alettiin rakentaa 1200-1300-lukujen vaihteessa, ja varhaisimmat nähtävissä olevat arkkitehtoniset tilat ovatkin keskiajalta. 1500-luvun loppupuoli on vahvasti edustettuna, sillä sitä voidaan pitää linnan loistokautena. Tuolloin Kustaa Vaasan poika, Suomen herttuaksi nimitetty Juhana asui linnassa ja rakennutti siihen kokonaan uuden kerroksen, joka nykyään tunnetaan renessanssikerroksena. Myös esilinnan kolme siipeä saivat silloin sen muodon, joka on nähtävissä edelleen.

Kustaa Vaasan pojanpoika Kustaa II Aadolf oli paikalla Turun linnassa, kun päälinnassa raivosi tulipalo 1614. Palanutta linnaa ei enää korjattukaan palatsiksi, vaan se alkoi hiljentyä. Valtionhallinnolliset toiminnot siirtyivät ensin esilinnaan ja sitten kokonaan pois linnasta Turun keskustaan. 1600-luvun loppupuolelta 1800-luvun loppuun Turun linnaa käytettiin lähinnä armeijan varastona, vilja-aittana ja vankilana. Viimeistenkin vankien siirryttyä Kakolan uuteen lääninvankilaan vuonna 1891 Turun kaupungin historiallista museota saatettiin ryhtyä laajentamaan. Turun linnan vanha pääosa kuitenkin pysyi autiona vielä pitkään.

Myös nämä restaurointia edeltäneet kolme autioitumisen ja rappeutumisen vuosisataa näkyvät Turun linnassa. Pyöreän tornin alimpaan kerrokseen on sisustettu uudestaan vankityrmiä ja päälinnan edelleen käytössä oleva, jatkosodan pommituksissa 1941 täydellisesti tuhoutunut kirkkosali on rekonstruoitu 1700-lukuiseen asuun, jossa se oli ennen palamistaan. Pääpaino on kuitenkin selvästi varhaisemmissa vuosisadoissa: 1700- ja 1800-luvut, linnan syvenevän rappion aika, jäävät keskiajan ja renessanssin kukoistuksen varjoon.

Lähtötilanne, jossa 1940-1960-lukujen restaurointeja tehtiin, oli se, että tuolloin vanhaksi linnaksi kutsuttu päälinna oli moni paikoin "kuin tyhjäksi puhallettu raunio" (Gardberg 1961b, 6). Puiset välipohjat oli suurelta osin mädäntyneinä ja vaarallisina purettu, ja jatkosodan pommitukset täydensivät tuhon. Sotavuosina linnaa ei ollut mahdollista ryhtyä korjaamaan. Restaurointisuunnitelmia oli kuitenkin tehty koko 1900-luvun alkupuoli, ja tulevan suururakan periaatteista oli sovittu jo vuonna 1936. Piirustuksia ja tarkkaa restaurointisuunnitelmaa tehtiin sodan kestäessä. Päämääränä oli sekä entistää (termi, jota tuolloin käytettiin) Turun linna että tehdä siitä uudestaan elävä ja toiminnallinen tila. Entistämisen jälkeen se olisi muistomerkki, mutta myös toimiva museo ja korkean tason juhlien viettopaikka. (Gardberg 1961a; Bryggman \& Cleve 1944.)

Entistämisen tuli tapahtua niin, että "sellainen mikä voidaan saattaa entiseen kuntoon, entistetään, jotavastoin suoranaisia uusintoja mikäli mahdollista vältetään" 


\section{TILALLISTA KERRONTAA TURUN LINNASSA}

(Bryggman \& Cleve 1944, 1). Terminologia on muuttunut sitten 1940-luvun (1), eikä restaurointitermien silloisia merkityksiä ole helppoa tavoittaa nykyajasta käsin. Ottaen huomioon funktionalistisen arkkitehtuurin käytännönläheisyyden tulkitsen kuitenkin, että entistämisellä, "entiseen kuntoon saattamisella", tarkoitettiin toimenpiteitä, jotka tehtäisiin mahdollisimman vähillä muutoksilla vallitsevaan tilanteeseen. Entistämisellä olisi näin ollen saatettu tila siihen muotoon, jossa se oli ollut ennen lopullista rappeutumistaan. Uusintamisella taas ymmärrän entistämistoimikunnan tarkoittaneen sellaisten arkkitehtonisten muotojen ja funktioiden palauttamista, jotka olivat jo kokonaan hävinneet joko uusien funktioiden tai esimerkiksi tulipalon aiheuttaman tuhoutumisen seurauksena.

Sekä Bryggman ja Cleve lakonisessa tilannekatsauksessaan että Gardberg tyyliltään runollisemmassa kuvauksessaan antavat ymmärtää, että Turun linnassa ei restaurointia edeltäneillä vuosikymmenillä ollut edes välipohjia, saati selvästi erottuvia huonetiloja. Tätä taustaa vasten ymmärrettyinä sekä "entistäminen" että "uusintaminen" edellyttivät muurien välisessä tyhjyydessä toimenpiteitä, joita nykypäivänä kutsutaan rekonstruoimiseksi. Vastoin alkuperäisiä suunnitelmia joitain huonetiloja päädyttiin siis myös "uusintamaan". Nykyajan Turun linnan kannalta keskeisin näistä esiin rakennetuista tiloista on huone, joka tunnetaan Keskiaikaisena kuninkaansalina.

Linnan vielä vastatessa alkuperäistä funktiotaan puolustus- ja asuinrakennuksena jokainen uusi rakennusvaihe liittyi tietenkin sitä edeltäneisiin vaiheisiin. Aina, kun linnaa ajanmukaistettiin, syntyi uusi tilallinen kerrostuma, joka oli useimmiten hallitsevassa suhteessa aikaisempiin. Vanhempien osien arkkitehtuuri ja funktiot elivät kulloisenkin tarpeen mukaan. Varsinkin Vaasa-suvun (kuningas Kustaa Vaasan ja hänen jälkeläistensä) rakennusprojekteissa 1500-luvulla tämä merkitsi usein myös esimerkiksi holvien kaltaisten, aikaisemmille vuosisadoille tyypillisten arkkitehtonisten piirteiden katoamista monista vanhemmista huoneista. Näin tapahtui myös huoneessa, joka oli keskiajalla ollut kuninkaansali. Herttua Juhanan toimeenpanemissa 1560-luvun muutostöissä sen holvit purettiin ja korvattiin palkkikatolla, jolloin tämän huoneen ja ylemmän kerroksen uuden salin välille oli mahdollista sijoittaa matala varastohuone, "tapettikamari". Entisestä kuninkaansalista tuli drabanttien eli herttuan henkivartijoiden tai seuralaisten tupa, ja edustustilat siirrettiin ylimmän kerroksen uusiin, valoisiin saleihin. (Gardberg 1959, 278.) Sittemmin siitä tuli samanlainen varastohuone kuin muistakin vanhan linnan autioituneista saleista. 1760-luvulla linnassa toimineen pastorin Eric Lennqvistin aikalaiskuvauksessa tuossa nimettömässä, "munkkikirkkoa vastapää̈a”" sijaitsevassa huoneessa riippui muun muassa suuri rautavaaka, jolla punnittiin ruutia ja salpietaria. Lisäksi siellä oli kasassa erilaisia vanhoja asetarpeita. (Lennqvist 1885, 82.) Keskiaikaisesta merkittävyydestä siellä ei enää ollut jälkeäkään.

Kun holveja ryhdyttiin rekonstruoimaan 1950-luvulla, työssä sovellettiin uusinta teknistä osaamista ja tietoa kunkin huoneen rakenteellisista erityisvaatimuksista. Keskiaikaisen kuninkaansalin kohdalla linnan ulkomuurit olivat niin heikot, ettei holveja voitu rakentaa niiden varaan. "Sen vuoksi noudatettiin toista periaatetta", kirjoittaa C. J. Gardberg raportissaan Turun linna ja sen restaurointi: "pilareihin porattiin läpikulkeva ontelo, johon sijoitettiin kantava teräsbetonirakenne. Lattian alapuolella jatkui teräsbetonipilari alemman kerroksen kautta aina kalliopohjaan.” (Gardberg 
1961a, 35.) Näin keskiaikaisen kuninkaansalin uusintamisella nykyaikaisin keinoin ja materiaalein vahvistettiin linnaa myös tulevaisuutta varten. Sen rakenteet lujittuivat samalla kun esteettisesti saavutettiin keskiaikainen monumentaalitila - seinien, holvien ja pilareiden betonipinnat slammattiin eli kevytrapattiin ja betonista valettu lattia verhottiin laudoilla, ikkunoihin laitettiin ranskalaista antiikkilasia ja rautapuitteet.

Moderni, rekonstruktiivinen väliintulo sai kuitenkin aikaan myös sen rakennushistoriallisesti anakronistisen tilanteen, että "keskiaika", "renessanssi" ja "moderni" arkkitehtonisesti luotuina tiloina ovat ensimmäistä kertaa historiassa koettavissa yhtaikaa. Vierailija voi käydä saman tunnin sisällä sekä keskiaikaisessa kuninkaansalissa että renessanssiajan herttuansalissa, joka on samalla myös 1950-lukuinen juhlasali 2000-luvun tilaisuuksille, esimerkiksi renessanssityylisille ruokapidoille (ks. Amica Juhlat Turku: Turun linnan juhlahuoneistot). Nykyhetki Turun linnassa laajenee tilalliseksi moniaikaisuudeksi.

\section{MIMESIS TULKINTA-AVAIMENA}

Restauroinnin yksityiskohtia lukiessa nykypäivän maallikonkin on helppo havaita, että Turun linna ei ole siinä määrin "aito keskiaikainen linna" kuin sen arkkitehtoninen estetiikka antaisi ymmärtää. Teräsbetonia ja muita uudenaikaisia materiaaleja on käytetty runsaasti, kaikki holvit eivät enää ole kantavia ja kronologisesti eriaikaisia tiloja on rakennettu esiin tavalla, joka ei ole yhtäpitävä menneiden aikojen todellisuuksien kanssa. Tästä näkökulmasta katsoen nykypäivän Turun linnaa temporaalisesti määrittävä aikakausi onkin moderni myös muissa kuin niissä funktionalistisissa tiloissa - ullakon näyttely- ja luentosaleissa ja sisääntuloaulassa - jotka rakennettiin linnaan kokonaan uusina arkkitehtonisina elementteinä.

Monumentaalisissa linnoissa ja muissa kulttuuriperintöympäristöissä on usein helppo unohtaa, että 100 tai 700 vuotta vanhan rakennuksen nykyaika on riippuvainen niiden ihmisten valinnoista ja arvotuksista, jotka ovat olleet niistä viimeksi vastuussa. Myös Turun linnan arkkitehtuuri on kaikkina aikoina heijastanut niitä funktionaalisia ja rakennustaiteellisia pyrkimyksiä, joita linnaa kulloinkin hallinnoivilla tahoilla on ollut. Keskiajalla se oli puolustuslinna, renessanssiajalla asuinpalatsi. 1940-1960-luvun suuressa restauroinnissa siitä tuli museo ja rakennusmuistomerkki. Modernia ajattelua edustaneiden 1900-luvun alkupuolen restauroijien ideaalit, motiivit ja tekniikat määrittelivät, millainen representaatio Turun linnan vuosisadoista tuleville sukupolville välittyy.

Arkkitehtuuria voidaan luonnehtia mimeettiseksi, jäljitteleväksi taiteenlajiksi: rakennustaiteen tuotteissa nostetaan usein esiin elementtejä niitä edeltäneistä rakennuksista. On vaikea kuvitella rakennusta, joka ei muistuttaisi mitään aikaisemmin nähtyä. Restaurointiarkkitehtuurissa mimesis on keskeinen osa prosessia, jossa jostakin rakenteesta tehdään aikaisemman kaltainen. Erityisen hyödylliseksi analyyttiseksi käsitteeksi mimesis tulee, jos restauroitua rakennusta tulkitaan narratiivisuuden näkökulmasta, niin kuin tässä teen folkloristina. Silloin olennaista on, että mimesis ei 
ole pelkästään jäljittelyä tai kopioimista, "saman" tuottamista. Mimeettinen prosessi on produktiivinen, se on luovaa imitointia, joka tuottaa jotain uutta.

Omaa tulkintaani mimesiksestä, uutta luovasta, kertovasta (menneen tai nykyisen) todellisuuden imitoimisesta on eniten inspiroinut Paul Ricoeurin 1980-luvulla esittämä kolmivaiheinen mimesis-malli. Sen avulla Ricoeur kuvaa ajallisen kokemuksen muotoutumista narratiiviksi ja edelleen narratiivin vaikutusta temporaaliseen kokemukseen. Ricoeurin mallin mimesiksen kolme vaihetta ovat yksinkertaistettuina esiymmärrys (pre-figuration), koostaminen (con-figuration) ja uudelleenhahmottaminen (re-figuration). (Ricoeur 1990, 52-71; termien suomennoksista ks. Ricoeur 2005.)

Ricoeurin mukaan toiminnan arkinenkin käsittäminen edellyttää ihmiseltä kulttuurisia valmiuksia (preliminary competence) hahmottaa tilanteista koodeja ja struktuureja (esimerkiksi toimijoita, heidän motiivejaan, tekojen seurauksia), toiminnallista symboliikkaa ja ajallisia rakenteita. Tämän kompleksisen, monitahoisen ja -tasoisen todellisuutta koskevan esiymmärryksen koostaminen kerronnaksi tapahtuu ennen kaikkea juonentamisen (2) (emplotment) avulla. Juonentamalla kertoja koostaa yksittäisistä tapahtumista ja toimijoista, ajallisista osatekijöistä ja olosuhteista kokonaisen, merkityksellisen kertomuksen. Kertomuksessa ei ole välttämätöntä piilottaa ristiriitoja ja odottamattomia tapahtumia vaan tehdä ne ymmärrettäviksi osana koherenttia juonta. Konfliktikin voi, kuten tunnettua, olla juuri se kertomus, joka halutaan kertoa. Ricoeurin mimesis-mallissa uudelleenhahmottamisen vaihe palauttaa narratiivin elävään elämään. Se, joka hahmottaa maailmaa uudelleen, on lukija tai kuulija, juonennetun ja kerrotun todellisuuskuvan haltuunottajaa ja käyttäjä. (Ricoeur 1990, 33-34, 52-71; Ricoeur 1991, 138.)

Paul Ricoeur käsittelee nimenomaan kielellistä kerrontaa, mutta minä sovellan tulkintaani hänen mimesis-mallistaan aineelliseen kerrontaan, Turun linnaan arkkitehtonisena ja tilallisena narratiivina. Turun linnassa on monenlaista yhtaikaista kerrontaa: ilmeisimpänä opastettujen kierrosten esittävä kerronta, joka tapahtuu arkkitehtonisesti tuotetuissa, opastetuilla kierroksilla aktuaalistuvissa tiloissa. Opastetuilla kierroksilla kertomukset menneisyydestä - Turun linnan ja Suomen ja Ruotsi-Suomen historiasta, historian pyörteistä tärkeiksi nostetuista henkilöhahmoista - nivotaan siihen aineelliseen tilaan, jossa kulloinkin ollaan tai sen representaatioon esimerkiksi pienoismallin muodossa. Turun linna tilana, restauroimalla tulkittuna ja erilaisissa toiminnallisissa ja kokemuksellisissa suhteissa merkityksellistyvänä aineellisena ympäristönä, on sekä muun kerronnan edellytys että sen tulos.

Koska Turun linnan tilallisessa narratiivissa on mielestäni kyse erityisesti ajallisuuden esittämisestä, käytän Ricoeurin mallia jäsentäessäni (ja juonentaessani) linnan ajan, paikan ja toiminnan suhteissa rakentuvaa, kerronnallisesti aktuaalistuvaa tilallisuutta. Tulkintaani sekä tilasta että mimesiksestä informoivat lisäksi niin sanotun uuden retoriikan konstruktiiviset lähtökohdat (ks. esim. Potter 2000). Näen arkkitehtonisesti ja kerronnallisesti rakennetun tilan siten myös tekona, jolla luodaan ja muokataan kuvaa todellisuudesta. Narratiivisen ja retorisen näkökulman suurimmaksi anniksi tilan tulkinnassa katson sen, että näin pystytään siirtymään eteenpäin pelkästä Turun linnan epäautenttisuuden toteamisesta, jota en pidä erityisen mielenkiintoisena. Haluan edelleen korostaa, että en myöskään käytä narratiivisen tilan tai tilan retoriikan 
kaltaisia konsepteja todistaakseni, että Turun linna olisi epäaito ja kerronta fiktiivistä. Folkloristinen kerronnantutkimukseni ei tähtää toden ja sille vastakkaisen epätoden osoittamiseen.

\section{JUONENNETTU LINNA}

Se Turun linnan Keskiaikainen kuninkaansali, jonka nykykävijä voi kokea, on arkkitehtonisena ja aikaan viittaavana tilana vaikuttava. Valkeat holvit kaartuvat kolmen pilarin ylle ja korkeat goottilaiset ikkunat antavat kauniisti valoa etelästä, linnanpihan puolelta. Keskiaikaisessa puolustuslinnassa ikkunoita ei turvallisuussyistä tehty ulkomuuriin, jossa sen sijaan kulki ampumakäytävä. Ulkomuuriin aukeaa kaksi ovea, joista toinen johtaa privettiin eli käymälään ja toinen säilytystilaan. Salin perällä on valtava avotakka. Ikkunaseinällä on juurakkojalkainen pöytä, muu kalustus koostuu neljästä vaakunasta pohjoisseinällä sekä muutamasta eleettömästä penkistä, jotka on tarkoitettu kävijöille. Niillä istuessaan voi lepuuttaa jalkojaan samalla kun ihailee keskiaikaista salia. Salin arkkitehtoninen kieli kertoo myös temporaalisuudesta. Vaikka tilasta ei edes sanallisesti kerrottaisi, että se on Keskiaikainen kuninkaansali, sen muotokieli viestittää vuosisatojen takaista juhlavuutta. 1600-luvun drabanttien tupa tai 1700-luvun epämääräinen asevarasto se ei ole.

1950-luvun restaurointiprojektissa rekonstruointeihin ryhdyttiin pääsääntöisesti vain silloin, kun katsottiin, että tilan aikaisemmasta arkkitehtuurista ja käytöstä oli tarpeeksi tietoa. (Ks. esim. Gardberg 1961a, 18.) Restaurointiprojektin perustana voidaan siis nähdä mimeettinen esiymmärrys Turun linnan menneisyydestä. Esiymmärrykseen johtanut tutkimustyö aloitettiin jo 1880-luvulla. Tuolloin katsottiin mahdolliseksi kirjoittaa "täydellinen historiallis-rakennustaiteellinen kertomus" siten, että se tehtäisiin "valtioarkistossa olevien, tähän tarkoitukseen käyttämättömien linnatilien ja muiden lähteiden johdolla" (ks. Valtiopäiväasiakirjat 1882).

Tämän työn suoritti arkkitehti Jac. Ahrenberg. Tutkielmassaan Ur Abo slotts byggnadshistoria (1901) hän kertoo hyödyntäneensä "jotakuinkin kaiken asiaa koskevan materiaalin”, käyneensä henkilökohtaisesti läpi osan Turussa sijaitsevassa valtionarkistossa säilytettävistä linnatileistä, mutta käyttäneensä myös laajasti A. H. Snellmanin kokoamia tietoja Analecta Archeologica Fennicasta sekä Ruotsin keskiaikaa ja renessanssiarkkitehtuuria käsitteleviä teoksia. (Ahrenberg 1901, "Företal".) Arkistotutkimustensa ja havaintojensa pohjalta Ahrenberg päätyi tekemään restaurointiehdotuksen, jossa Turun linna olisi ulkoisesti palautettu renessanssiasuunsa. Sen lisäksi että renessanssi oli Turun linnan kulta-aikaa, siitä oli myös eniten tietoa saatavissa. Vanhan linnan tilajaot selviäisivät riittävässä määrin vuodelta 1751 olemassaolevista vanhimmista piirroksista. Parhaat ja oikeimmat tulokset linnan restauroinnissa voitiin Ahrenbergin mielestä kuitenkin saavuttaa ainoastaan siten, että Turun linnaa vertailtaisiin muihin samaa aikakautta edustaviin ruotsalaislinnoihin. Ahrenbergin voidaan ajatella näin tavoitelleen vankempaa kulttuurista esiymmärrystä siitä linnatyypistä, jollaisena hän Turun linnankin näki. Hänen suunnitelmassaan näkyvä mimesis on 


\section{TILALLISTA KERRONTAA TURUN LINNASSA}

hyvin konkreettisesti jäljentämistä. Vanhojen mittauspiirrosten ja pohjoismaisten esikuvien mukaisesti rakennettaisiin uudelleen (vain) ne huoneet, joiden varmasti tiedettäisiin aikanaan muodostaneen Vaasa-kuninkaitten huoneiston - "ja jotka nyt ovat niin pahoin vaurioituneita, että ne tuskin enää ovat huoneita lainkaan". (Ahrenberg 1901, 192; suom. PA.)

Jo 1900-luvun alkuvuosina kallistuttiin kuitenkin sille kannalle, että restaurointia ei tulisi tehdä ilman perusteellisia rakennushistoriallisia ja arkeologisia tutkimuksia. Ahrenbergin suunnitelmia ei näin ollen toteutettu kuin paikoitellen esilinnassa. Arkeologi Juhani Rinteen johdolla tutkimuksia ja mittauksia tehtiin 1900luvun alkuvuosikymmenet - sikäli kuin Turun tuomiokirkon restauroinnilta aikaa ja rahallisia resursseja liikeni. Rakennusarkeologiset tutkimukset laajensivat tietämystä linnasta erityisesti keskiajan suuntaan. Eniten tietoa oli kuitenkin Vaasojen ajasta Turun linnasta. Vuonna 1959 ilmestyi C. J. Gardbergin väitöskirja Abo slott under den äldre vasatiden. En byggnadshistorisk undersökning, joka on edelleen laajin Turun linnan rakennushistoriaa käsittelevä monografia - ja tiedollinen monumentti itsessään.

Käytännön restaurointityötä voidaan tarkastella menneisyyttä koskevan, monimuotoisen tietämyksen juonentamisena. 1940-1960 -lukujen restaurointiprojektissa tehtiin päätökset siitä, mitä linnan 700 -vuotisesta historiasta otetaan keskiöön ja mitä jätetään syrjemmälle. Turun linnan historiasta nostettiin kaksi pääasiallista ajallista kehystä, keskiaika ja renessanssi. Keskeinen kertomus menneisyydestä rakentuu niiden varaan. Tilallisen juonentamisen kannalta oli tärkeää, että linnan eri osien välille avattiin myös aineellisesti uusia yhteyksiä. Jo 1944 julkaistussa Entistämisehdotuksessa esitetään, että Turun linnan rakenteisiin tehdään joitakin uusia portaita ja kulkuväyliä, jotta linnassa kiertäminen tulisi mahdolliseksi (Bryggman \& Cleve 1944, 2).

Rakennusmonumentin museaalinen infrastruktuuri on moderni. Funktionalistisen arkkitehdin Erik Bryggmanin kädenjälki näkyy erityisesti päälinnan sisääntuloaulassa ja ullakoille rakennetuissa näyttelysaleissa, ja juhlahuoneistona palvelevien renessanssisalien kalustuksen suunnitteli hänen tyttärensä, sisustusarkkitehti Karin Bryggman. Eteishallista tuli rakennusmonumentin infrastruktuurin keskus. Se on jaettu kahteen tasoon, mikä toisaalta viittaa vuosisatojen takaiseen tilajakoon ja toisaalta on edellytys sille, että kiertokulku linnassa onnistuu. Eri osissa päälinnaa on myös vaakasuunnassa pieniä käytäviä ja oviaukkoja, jotka on rakennettu 1950-luvulla helpottamaan linnassa kulkemista. Pystysuunnassa on joitakin portaita sekä tietenkin hissikuilu, joka kohoaa läpi linnan ensimmäisestä kerroksesta kuudenteen kerrokseen saakka. Nämä rakenteet ovat suunnitelman mukaisesti tehneet mahdolliseksi sen, että Turun linna pää- ja esilinnoineen todellakin voidaan kiertää sisäkautta ympäri asti - ensimmäistä kertaa sen rakennushistorian aikana. (3)

Kokonaan uusien rakenteiden oli tarkoitus erottua niin selvästi vanhoista, että kävijäkin sen huomaisi. Uuden ja vanhan erottumisen periaate ei kuitenkaan ulotu niihin huonetiloihin, jotka on rekonstruoitu täydellisestä tuhosta uuteen arvokkuuteen. Restaurointityössä noudatettiin enimmäkseen sitä perusajatusta, johon jo viittasin: entistetään eikä uusinneta. Keskiaikaisen kuninkaansalin rekonstruoiminen uusintamalla eli tavalla, joka ohitti keskiaikaa myöhäisemmät vaiheet, on kuitenkin hyvä esimerkki siitä, että rekonstruktioille on ollut myös muita kuin käytännöllisiä motiiveja. 
Keskiaikaisen kuninkaansalin rekonstruointia edeltäneen Nunnakappelin uudelleen holvaamisen perusteena oli C. J. Gardbergin mukaan, että se oli ollut Suomen ensimmäinen tähtiholvi. (Gardberg 1961a, 8.) Nunnakappelin holvaaminen kuului jo vuonna 1944 julkaistuun Entistämisehdotukseen. Keskiaikainen kuninkaansali sen sijaan oli alunperin tarkoitus jättää holvaamatta. (Bryggman \& Cleve 1944.) Kun työt Nunnakappelissa talvella 1951-1952 kuitenkin onnistuivat erinomaisesti, Keskiaikaisen kuninkaansalin holvaaminen otettiin uudelleen harkintaan: 'Tosin voitiin väittää, että vallitsevat restauroimisperiaatteet vaativat huoneen konservoimista nykyiseen asuunsa, mutta toisaalta tuntui houkuttelevalta rekonstruoida huone, jonka voi uskoa olleen Suomen merkittävin profaani interiööri keskiajalla." (Gardberg 1961a, 35.)

Jos restaurointia ajatellaan juonentamisena, näiden kahden tilan holvaaminen voidaan tulkita kerronnalliseksi valinnaksi. Pilarien, holvikaarien ja muurien välinen funktionaalinen suhde on 1950-luvulla "perusteellisten tutkimusten ja pitkien keskustelujen jälkeen" (Gardberg 1961a, 35) toteutetun rekonstruointityön tuloksena rakenteellisesti toinen kuin aiemmilla vuosisadoilla. Menneisyyden representoimisen kannalta ne ovat kuitenkin aivan keskeisiä arkkitehtonisia muotoja. Rekonstruoimalla Nunnakappeli Suomen historian ensimmäisine tähtiholveineen ja Keskiaikainen kuninkaansali, joka oli maallisen vallan keskus keskiaikaisen Suomen alueella, juonennettiin tilallista narratiivia Turun linnasta nimenomaan keskiaikaisena linnana, joka oli ja on tällä maantieteellisellä alueella tärkeä. Samalla imitaatio oli kuitenkin myös uutta luovaa: 1950-luvun insinööritaidolla vahvistettiin linnan rakenteita.

Turun linnassa tilojen nimet ovat luettavissa kunkin huoneen seinään kiinnitetystä metallilevystä ja näillä nimillä huoneisiin viitataan opaskirjoissakin (ks. esim. Puhakka \& Grönros 1995). Keskiaikainen kuninkaansali kiinnittyy sekä arkkitehtonisesti että sille annetun nimen kautta keskiaikaan. Nunnakappeli sen sijaan viittaa tässä suhteessa temporaalisesti kahtaalle ja toimii kerronnallisena siltana keskiajan ja renessanssin välillä. Huone rakennettiin 1400-luvulla, Sten Sturen kaudella, jolloin Turun linnasta tuli todellinen herttuanlinna. Knut Draken mukaan huoneen ensimmäinen funktio oli toimia uutena juhlasalina, Gardbergin aiemman tulkinnan mukaan se taas rakennettiin suoraan kappeliksi (Drake 2000, 17; Gardberg 1959, 42). Lennqvist joka tapauksessa käyttää siitä 1760-luvun tekstissään nimitystä "den forna Munck Kyrckan” (Lennqvist 1885, 82).

Tiedossani ei ole, milloin "munkki" korvautui "nunnalla" tästä tilasta puhuttaessa. Sisällöllisesti nunna viittaa Katariina Jagellonicaan, puolalaiseen, katoliseen prinsessaan, josta tuli herttua Juhanan puoliso vuonna 1562. Kustaa Vaasan alaisessa Ruotsissa uskonpuhdistus oli virallisesti alkanut jo 1527. Katariina toi erityisluvalla linnaan sekä katolisen hoviväkensä että pappinsa, ja ilmeisesti tila oli tuolloin heidän käytössään kappelina. Juhana-herttuan ja Katariina Jagellonican lyhyttä yhteistä kautta linnassa pidetään Turun linnan renessanssina. Katariinaan viittaavassa Nunnakappelissa on kuitenkin esillä osa Turun maakuntamuseon laajasta keskiaikaisten veistosten kokoelmasta, mikä vahvistaa tilan juonentumista visuaalisesti keskiaikaiseksi. (Lepokorpi 2000, 33-37; Puhakka \& Grönros 1995, 55-56; Drake 1995, 54). 


\section{Herttua Juhana ja Katarina Jagellonica AJALLISUUKSIEN VÄLITTÄJINÄ}

Edellä olen soveltanut kolmivaiheista mimes-mallia Turun linnan tilallisen narratiivin tulkintaan siten, että tutkimustieto Turun linnan historiasta (paitsi rakennus- ja taidehistorian, myös poliittisen ja sosiaalihistorian kannalta), restaurointiajankohdan kulttuuriset arvot ja silloiset restaurointi-ideaalit muodostavat esiymmärryksen tason. Tulkitsevan juonentamisen tason näen restaurointiprosesseissa, joissa menneisyyden tilat rakennettiin uudelleen esiin. Uudelleenhahmottamisen vaihe aktuaalistuu tässä sovelluksessa opastetuilla kierroksilla. Lukijoina eli juonennetun narratiivin haltuunottajina voidaan pitää näkökulmasta riippuen joko kierrokselle osallistuvia vierailijoita tai oppaita. Molemmat näkökulmat avaavat edelleen linnaa tilallisena narratiivina.

Jos mimesis-mallin kolmanneksi vaiheeksi valitaan vierailijan kokemus, mimeettinen ketju etenee (I) linnan historiasta (II) restauroimalla juonennettuun tilalliseen narratiiviin, jota opas täydentää ja tulkitsee omalla kerronnallaan. Oppaan kerronnan omaksuminen (III) muokkaa vierailijan omaa tulkintaa ja kokemusta tilasta (ajan ja paikan suhteista) ja mahdollisesti omasta itsestään ajallisessa ja paikallisessa tilassa. Linnan restauroijat ovat juonentaneet ja välittäneet temporaalisuuksia arkkitehtonisten valintojen kautta. Oppaiden kerronnassa tilan aikaulottuvuus juonentuu myös niissä henkilöhahmoissa, jotka narratiiveissa elävät ja toimivat ympärillä nähdyissä ja tulkituissa arkkitehtonisissa tiloissa.

Herttua Juhana perhekuntineen on hyvin edustettuna opastettujen kierrosten kerronnassa. Tähän on varmasti se käytännön syy, että Vaasojen ajalta on paljon erilaista arkistomateriaalia, tilikirjoja ja säilynyttä kirjeenvaihtoa, jonka pohjalta Turun linnan 1500-luvun lopun historiaa on voitu konstruoida. Turun linnan tilallisuuden aika-ulottuvuudessa Vaasoilla on kuitenkin myös oma, narratiivinen erityistehtävänsä. Vaasojen ja erityisesti Juhana-herttuan ja Katariina Jagellonican aika ankkuroituu kahden kulttuurisesti määritellyn aikakauden väliin. Heidän renessanssiloistonsa Turun linnassa kesti vain kahdeksan kuukautta, mikä osaltaan tekee helpoksi nähdä sen dramaattisena taitekohtana ajallisessa narratiivissa.

Rakenteellisesti renessanssi paikallistuu tietenkin erityisesti niin sanottuun renessanssikerrokseen, uuteen kerrokseen, jonka herttua Juhana rakennutti keskiaikaisten osien päälle. Renessanssi kuitenkin ulottuu myös ns. "keskiaikakerrokseen" - esimerkiksi juuri Nunnakappeliin edellä kuvaamallani tavalla, mutta myös Keskiaikaiseen kuninkaansaliin. Vaikka sen funktio linnan monumentaalisessa kokonaisuudessa on representoida nimenomaan keskiaikaa, monet oppaat kertovat juuri siellä keskiaikaisten asioiden lisäksi Juhana-herttuan ja Katariina Jagellonican juhlista ja tuon ajan ruokatavoista. Näin siitä huolimatta, että Katariinan saapuessa linnaan uudenaikaisine haarukoineen vanha kuninkaansali oli jo drabanttien hallussa ja juhlat juhlittiin uusissa saleissa.

Jos siis mimeettisen mallin mukaan tulkitussa Turun linnassa kolmantena, uudelleenhahmottamisen vaiheena on vieraan kokemus, linnan narratiivisesta tilasta tulee oppaiden kerrontaan yhdistyneenä 2000-luvun ja 1300-luvun välille laajeneva 
aika-avaruus. Opastetuilla kierroksilla menneisyys juonentuu niin, että kuulijat voivat hahmottaa menneisyyttä ja paikkaa, jossa "menneisyys tapahtui" jostakin hetkestä käsin; se hetki on Juhanan ja Katariinan aika Turun linnassa. Vierailijoiden elämä nykyaika vertautuu sekä siihen menneisyyteen, joka oli myös herttuaparin menneisyyttä, että siihen menneisyyteen, joka oli vielä heidän tulevaisuuttaan. Juhanan ja Katariinan elämä aika on eräänlainen näköalatasanne, ajallinen paikka (eli tila), josta käsin katsotaan ajassa ja paikassa sekä taakse- että eteenpäin.

Vaihtamalla näkökulmaa siten, että "lukijaksi" otetaan Turun linnassa työskentelevä opas, saadaan näkyville uusi mimeettinen ketju. Oppaan työ tapahtuu sillä reitillä, joka Turun linnaan päälinnan suuren restaurointiurakan kuluessa 1940-1960-luvuilla rakennettiin. Reitti on pääpiirteissään hahmoteltuna jo vuonna 1944 julkaistussa Entistämisehdotuksessa (Bryggman \& Cleve 1944, 2), joskin se toteutetaan nykyisin toisin. Oppaiden voidaan ajatella elävän todeksi sitä, mikä Turun linnasta restauroinneissa tuli. Tilat ja niihin sisäänrakennettu eli -kirjoitettu narratiivi voitaisiin tästä näkökulmasta katsoen ajatella kulttuurisen esiymmärryksen tasoksi. Juonentajia ovat varsinkin uuden oppaan kannalta erityisesti C. J. Gardberg, mutta myös muut tutkijat Turun linnan historiaa käsittelevissä teoksissaan ja artikkeleissaan. Tehtäväänsä valmistautuessaan uudet oppaat lukevat näitä kirjoja ja osallistuvat vanhempien oppaiden kierroksille. Uuden oppaan oma kierros olisi näin ollen jo arkkitehtonisen, ajallisen ja paikallisen tilan "uudelleenhahmottamisen" vaihe.

\section{TEKSTISTÄ TILAKSI: TURUN LINNAN TONTTU-UKKO}

Linna tosiaankin on vielä koossa tänäkin päivänä. Se on taideteos, jonka kaltaista ei toinen niin helposti teekään. Koetapas rakentaa muuri, anna tulen sitä hävitellä, luotien runnella, sateen turmella, pakkasen halkoa, myrskyn täristellä, rottien kaivella ja vankien murtaa; anna muurin seistä sitten seitsemänsataa vuotta ihan hoitamatta; niin siten saat koetelluksi, kestääkö se! Mutta katsokaas, se muuri, jota sanotaan Turun linnaksi, nauraa vain ajan hampaalle ja pysyy koossa! Ihmekö siis, että vanhanaikaiset ihmiset uskoivat olevan tonttu-ukkoja? (Topelius 2000 [1849], 60.)

Vaikka tässä sadun päättävässä kappaleessa Topelius selittää tontun vanhan kansan uskomusolennoksi, tonttu-ukko itse asuu edelleen Turun linnassa. Hänen kamarinsa tosin on kohotettu Topeliuksen kuvaamasta maanalaisesta onkalosta esilinnan eteläsiiven kuusikulmaiseen torniin. Turun linnan tonttu-ukon kautta voidaan tarkastella myös tekstin ja tilan vuorovaikutusta mimeettisenä prosessina.

Satu Turun linnan tonttu-ukosta ilmestyi ensimmäisen kerran vuonna 1849 kokoelmassa Sagor. Sen keskiössä on Turun linna, jonka vanhat muurit vastustavat ajan hammasta paitsi tontu-ukon myös eläkkeelle jääneen vahtimestarin Matti Kivisen jatkuvan huolenpidon ansiosta. Sadussa Topelius ei tarkenna, mihin kronologiseen 


\section{TILALIISTA KERRONTAA TURUN LINNASSA}

aikaan kertomus Kivisen ja tontun yhteisistä ponnistuksista Turun linnan hyväksi sijoittuu, menneisyyteen kyllä, mutta ei kovin kauas. 1800-luvun tilanteeseen nähden Topeliuksen Tonttu-ukkoon luoma linnaympäristö on kovin rauhallinen ja erikoisen tyhjä. Hän esimerkiksi kyllä viittaa vankeihin, joita vartioidaan viiden miehen voimin, mutta sotaväkeä ei edes mainita (Topelius 2000 [1849], 53). Sadun kirjoittamisen aikaan linnassa oli kuitenkin satakunta vankia ja koko esilinnan pohjoissiipi oli venäläisen sotaväen hallussa (Lepokorpi 2000, 80).

Sadussa olevaa Turun linnan kuvausta tarkemmin luettaessa voidaankin huomata, että se heijastaa selvästi niitä tietoja ja tunnelmia, joita Eric Lennqvist kirjasi linnasta 1700-luvun jälkipuoliskolla. Osia tutkielmasta oli julkaistu Mnemosyne-lehdessä vuosien 1822 ja 1823 välillä, ja toinen tunnetuista Lennqvistin käsikirjoituksista oli jopa ollut Z. Topeliuksen isän hallussa vuoteen 1822. Esimerkiksi Lennqvistin kuvaus - "Kaikkia ikkunoita ei ole täällä laudoitettu kerralla, ja niitä, jotka on sillä tavoin suljettu jo kauan sitten, ei ole korjattu, niin että rajuilmalla pyryttää sisään suuria lumikinoksia, jotka mädättävät lattiat tai pohjat hirsineen ja parruineen” (Lennqvist 1885, 84, suom. PA) - näyttää Topeliuksen versiossa, uusilla yksityiskohdilla ja hyvinvalituilla verbeillä elävöitettynä, muodostavan sekä Kivisen ja tontun toimintaympäristön että kuvauksen heidän tehtävistään:

[Kivisellä] oli nyt kylliksi aikaa kävellä ja kaivella vanhassa linnassa miten mielensä teki, korjailla puutteellisuuksia, tukkia rikkonaisia ikkunaruutuja, joista myrsky puhalteli sisään syysöinä, taikka estää lunta ja sadetta vuotamasta katon raoista.

$[\ldots]$

Tuli sitä raateli, samoin aika; talvet tuiskuttivat lunta sisään, kesät satoivat vettä, tuuli ravisteli tiiliä ja savupiippuja, rotat kalusivat reikiä lattiaan, tikka hakkasi rikki ikkunain pielet, hirret mätänivät, kellariholvit uhkasivat pudota romahtaa alas ja tornit näyttivät jo hyvin arveluttavasti kallistuvan. Turun linnasta ei kohta olisi ollut muuta jälellä kuin soraläjä, ellei tonttu alinomaa olisi korjaillut vaurioita ja nyt hänelle tuli avuksi vanhus Kivinen. (Topelius 2000 [1849], 16-17.)

Topelius siis kertasi sadussaan Eric Lenncvistin kuvausta Turun linnasta ja sijoitti siihen ympäristöön uskomusolennon ja fiktiivisen vahtimestarin. Sadusta tuli suosittu, ja linnantontusta sadun myötä narratiivinen monitoimimies. Viitisentoista vuotta myöhemmin, vuonna 1865, Ábo Underrättelser-lehden päätoimittaja J. W. Lillja vietti kuukauden vankina Turun linnassa kirjoitettuaan valtiovaltaa loukkaavaa tekstiä Puolan tapahtumista. (Autero 1993, 368-370.) Linnassa yksityissellissä istuessaan J. W. Lillja otti kantaa suunnitelmiin rakentaa Turun linnaan enemmänkin sellivankiloita silloisten yhteisvankiloiden sijaan. Kuinka ollakaan, Lillja valjastaa rakennusasiantuntijaksi Turun linnan tonttu-ukon.

Yhtenä yönä täällä myrskysi kauheasti; ihmeellinen ujellus, voihkina ja sähinä, jonka myrsky sai aikaan nurkissa ja sopissa, manasi mielikuvituk- 


\section{Petja Aarnipuu}

sesta esiin myös kaikenlaisia ajatuksia hengistä ja kummituksista, ja Z. T:n tarinoiden kuvat Turun linnan Tonttu-ukosta näyttäytyivät minulle varsin eloisina. Menin sänkyyn ja nukahdin näiden ei lainkaan epämiellyttävien fantasioiden virratessa, ja ne jatkuivat unessakin. Nytpä avautui narisevilla saranoillaan ovi erääseen vanhaan holviin, ja sieltä asteli Tonttu-ukko. (Lillja 1865; suom. PA.)

Unen muotoon puetussa kannanotossa tonttu valittaa, ettei linnassa saa enää mitään rauhaa, kun ihmiset, joista ei ollut kuultukaan siihen aikaan kun jättiläiset linnaa rakensivat, mittailevat ja tutkivat ympäriinsä. - "Dessa personer kalla sig arkitekter", tonttu huomauttaa.

Sittemmin, 1900-luvun alussa, tontun otti kriittiseksi retoriseksi tuekseen myös arkkitehti Gustaf Nyström. Hän puolestaan kritisoi jyrkästi Jac. Ahrenbergin aikomusta ryhtyä suuriin rekonstruktioihin pelkkien arkistotutkimusten perusteella. Nyström kirjoitti valtionarkeologi Aspelinille:

Et saata uskoa, miten hauskaa linnan vanhoilla kunniallisilla tontuilla ja minulla oli, kun tapasimme siellä alhaalla holveissa ja nauroimme keskenämme aikamme oppineille tutkijoille, jotka etsivät ja uskovat löytävänsä Turun linnan historian valtionarkiston hyllyiltä eivätkä ole selvillä, että linnan jokaisella kivellä on historia kerrottavanaan elävämpänä, todempana kuin kaikki musteella präntätty perimätieto. (Teoksessa Gardberg 2002, 287.)

Edellä analysoimani tilallinen narratiivi osoittaa, että kivet ja muurit eivät suinkaan aina jää hiljaisiksi historian todistajiksi. Tonttu-ukon tapauksessa kokonainen huone Turun linnassa on sisustettu tontusta kertovaksi tilaksi. Sen yksityiskohdat viittaavat suoraan Topeliuksen 1840-luvulla kirjoittamaan satuun ja sen kautta tila laajentuu muissa teksteissä kuvattuihin, aikaisempiin tilallisuuksiin. Erityissuhde on nähtävissä Topeliuksen tekstin kautta Eric Lenqvistin 1760-luvulla tekstissään kertomaan, säänpieksemään vankilalinnaan.

Huoneessa, josta sittemmin tuli Tonttu-ukon kamari, asui 1950-luvulla museonvartija Alexandra Fredriksson (1877-1956). Voitaisiin ehkä ajatella, että Alexandra Fredriksson jatkoi Topeliuksen sadussaan kuvaaman vanhan vahtimestari Matti Kivisen kunniakasta työtä Turun linnan hyväksi. Topeliuksen Kivinen "hoiti virkaansa kunnialla viisikymmentä vuotta" ja jatkoi eläkkeelle jäätyään samoja toimia, joilla tonttukin liikkui: "sillä molemmat he rakastivat linnaansa enemmän kuin mitään muuta tässä maailmassa, eivätkä pitäneet lukua vaivoistansa korjaillessaan rappeutuvia muureja" (Topelius 2000 [1849], 17). Sandra Fredrikssonista kerrotaan niinikään, että hän ei museon parasta ajatellessaan koskaan säästänyt itseään. Rakkaudesta linnaan ja historiaan hänkin teki korkeaan ikään saakka niitä tehtäviä, jotka piti tehdä - aivan riippumatta varsinaisesta toimenkuvastaan. (Sahlberg 1957, 117.)

Miespolvet vaipuvat yleisesti ottaen unholaan, ja niin myös "Fredrikssonin täti” on muistona enää hänet joskus tunteneiden aikalaisten mielessä. Vaikka Sandra 


\section{TILALLISTA KERRONTAA TURUN LINNASSA}

Fredriksson on linnassa kerran elänyt ja työtä tehnyt ihminen (ks. tarkemmin myös Aarnipuu 2006, 244-246), tonttu taas, sikäli kuin Topeliusta on uskominen, satuhahmo, tonttu on näistä kahdesta se, jolla on nimissään sekä Sandran asunto että oma opastettu kierros. Kulttuuriperintöympäristölle onkin tyypillistä, että vain jotkut harvat yksilöt jäävät eloon ja elävöittämään monumentaalista, muistoa luovaa ja säilyttävää tilaa. Tonttu-ukon esimerkki osoittaa, että tilassa elävä hahmo voi olla myös ilmeisen fiktiivinen ja narratiivinen henkilö.

Sandran kaltaisia, viimeiseen saakka linnamuseon hyväksi työtä tehneitä ihmisiä on monia muitakin. Usein heidän panostaan kiitetään Turun kaupungin historiallisen museon vuosikirjoissa silloin, kun on koittanut muistokirjoituksen aika. Fiktiivisenä hahmona Turun linnan tonttu-ukko edustaa tulkintani mukaan kaikkia niitä menneitä sukupolvia, jotka ovat hävinneet tilallisista muistoista mutta joita ilman linnan muurit ja kivet eivät"nauraisi ajan hampaalle" tai "kertoisi historiaa". Herttua Juhanan ja Katariina Jagellonican hahmojen kautta, kuten edellä väitin, voidaan siirtyä ja pysähtyä johonkin kohtaan ajallisuudessa. Tonttu-ukon hahmoa sen sijaan käytetään, kun halutaan juonentaa ajallista jatkumoa, sitä, mikä on ollut aina tai ainakin viimeiset 700 vuotta - esimerkiksi lakkaamatonta työtä, jota aikakirjoista hävinneet ihmiset ovat tehneet Turun linnan arkipäivässä. Tavallisuudessaan he ovat monumentaalisessa ympäristössä yhtä näkymättömiä kuin tonttu, jolla on lakki oikeinpäin päässään (ks. Topelius 2000 [1849], 16), ja yhtä tärkeitä linnan kannalta. Tästä narratiivisesta, juonentavasta näkökulmasta katsottuna - ja nyt juonentajana olen minä tutkijana ja tulkitsijana - nykyinen, tosi mutta fiktiivinen tonttu-ukon kamari kaikkine romuineen, aarteineen ja täytettyine susineen ei olekaan niin kaukana siitä siististä asunnosta, joka oli kerran Fredrikssonin tädin koti.

\section{TÄHÄN ON TULTU}

Arkisilla ajan ja paikan määrityksillä voidaan rakentaa toimintaohjeita ja karttoja. Esimerkiksi johonkin kokoukseen osallistujat löytävät perille, jos heille ilmoitetaan seuraavat spatio-temporaaliset koordinaatit:

Aika: 20.6.2007 klo 15.00

Paikka: Turun linna

Tila: Bryggman-sali

Turun linnan tarkastelu narratiivisena, juonennettuna ja juonentavana tilana valaisee sen nykyistä luonnetta kansallisesti merkittävänä kulttuuriperintökohteena. Tällöin ei ole enää kysymys siitä, miten päästään jonnekin, vaan siitä, minne on tultu. Tilallisen kerronnan näkökulmasta Turun linnassa kävijälle ajassa ja paikassa suunnistamisen tueksi annettavat koordinaatit voivatkin olla vaikkapa seuraavanlaiset:

Aika: vuosi 1380 


\section{Petja Aarnipuu}

Paikka: Turun linna

Tila: kuninkaansali

Monumentaalinen tila muistuttaa - Lefebvren mukaan jopa totalitaarisuuteen asti: "monumentaaliset rakennukset naamioivat vallanhimon ja vallan keinotekoisuuden sellaisten merkkien ja pintojen alle, jotka väittävät ilmaisevansa kollektiivista tahtoa ja kollektiivista ajattelua" (Lefebvre 1994, 143, suom. PA). Kansallisen kulttuuriperinnön analysoiminen tilan kautta ja tilassa tapahtuvan kerronnan näkökulmasta puolestaan auttaa muistamaan, että myös kulttuuriperintöilmiöt ovat kiinni ajassa ja ihmisissä, jotka tulkitsevat ja tekevät valintoja. Minusta tämä on omiaan inhimillistämään ja avaamaan monumenttia.

Juonentamisen, kerronnallisesti tapahtuvan merkitysten luomisen ja välittämisen ajatus on mielestäni erityisen hedelmällinen kun ajatellaan niitä ristiaallokkoja, joita aiheuttavat "historia" ja matkailuteollisuus kohdatessaan. Voisi kuvitella, että Turun linnalla ei ole pääsyä UNESCOn maailmanperintölistalle muun muassa 1940-1960luvuilla tehtyjen restaurointitoimien vuoksi. Teräsbetonin määrä on liian suuri, jotta se olisi aito keskiaikainen linna. Kuten edellä esittämästäni käy ilmi, kulttuuriperintönä Turun linna on kuitenkin voimissaan sekä kansallisen omaisuuden että menneisyyttä koskevan tiedon eteenpäin kantamisen näkökulmasta.

Narratiiviset mimesis-ketjut eivät ole pelkästään yksisuuntaisten tulkinnallisten suhteiden kuvaamisen tai todentamisen välineitä. Se, mitä linnasta on kerrottu, on vaikuttanut siihen, millaiseksi linna on restauroitu. Restauroitu linnaympäristö taas vaikuttaa edelleen siihen, miten linna koetaan ja mitä siitä kerrotaan. Turun linnan kertojina voidaan siis pitää näkökulmasta riippuen esimerkiksi linnan rakentajia tai linnan restauroijia, linnan historian kirjoittajia tai sen tulkitsijoita. Tekstit, tilat, kirjoittajat, näkijät, suunnittelijat, rakentajat, tulkitsijat ja kokijat ovat monitasoisissa ajallisissa ja paikallisisssa vuorovaikutussuhteissa keskenään. Mimesis-mallin avulla pyrin hahmottamaan niitä kompleksisia ja moniulotteisia narratiivisia prosesseja, jotka tekevät Turun linnasta kulttuuriperintökohteen.

\section{VIITTEET}

1. Nykyisin käytössä olevista restaurointitermeistä ks. esim. Valtion rakennusperinnön vaaliminen 1997, 13.

2. Haluan käyttää Matti Hyvärisen suosimaa "juonentamista" (ks. esim. Hyvärinen 2004 ja Hyvärinen 2006) yleisemmin käytössä olevan "juonellistamisen" sijaan, koska se muistuttaa muodoltaan esimerkiksi "suomentamista". Mimesis-teorian yhteydessä tällainen viite tulkitsevaan kääntämiseen on mielestäni osuva.

3. Esimerkiksi keskiajalla ajatus toisiinsa yhteydessä olevista tiloista olisi ollut järjetön. Linna oli puolustusrakenne, ja erilliset, vain helposti purettavien solakäytävien kautta saavutettavia huoneistoja oli mahdollista puolustaa tehokkaasti. 


\section{TILALLISTA KERRONTAA TURUN LINNASSA}

\section{KirjallisuUs}

AARNIPUU, PETJA 2006: Avaimet suureen porttiin. Kehkeytyviä tiloja Turun linnassa. - Laaksonen, Pekka \& Knuuttila, Seppo \& Piela, Ulla (toim.), Paikeka. Eletty, kuviteltu, kerrottu. Kalevalaseuran vuosikirja 85. Helsinki: Suomalaisen Kirjallisuuden Seura.

AHRENBERG, JAC. 1901: Ur Abo slotts byggnadshistoria. Anteckningar och paralleler I anledning af frägan om Abo slotts restoration. Helsingfors: Finsk tidskrifts tryckeri aktiebolag.

AMICA JUHLAT TURKU [online] 2007. < www.juhlatturku.fi >. [Viitattu 8.3.2007.]

APPELGREN, KARI 2000: Turun linnan tyyli-interiöörit - Puhakka, Martti (toim.), Turun linna. Turku: Turun maakuntamuseo.

AUTERO, OLAVI 1993: J. W. Lillja 1817-1878. Kirjamiehestä poliittiseksi taistelijaksi. Historiallisia tutkimuksia 172. Helsinki: Suomen Historiallinen Seura.

BRYGGMAN, ERIK \& CLEVE, NILS 1944: Turun linnan entistämisehdotus. Helsinki: Suomalaisen Kirjallisuuden Seura.

CERTEAU, MICHEL DE 2002: The Practice of Everyday Life. Berkeley: University of California Press. [1974]

DRAKE, KNUT 1995: Menneisyys, nykyisyys, tulevaisuns. Turun kaupungin historiallinen museo - Turun maakuntamuseo 1881-1981. Turku: Turun maakuntamuseo.

GARDBERG, C. J. 1959: Abo slott under den äldre vasatiden. En byggnadshistorisk undersökning. Suomen muinaismuistoyhdistyksen aikakauskirja 60. Helsinki: Suomen muinaismuistoyhdistys.

- 1961 a: Turun linna ja sen restaurointi. Turku: Turun kaupunki.

- 1961b: Turun linna. Vanban osan esittely. Turku: Turun kaupungin historiallinen museo.

— 2002: Kivestä ja punsta. Suomen linnoja, kartanoita ja kirkekoja. Helsinki: Otava.

HYVÄRINEN, MATTI 2004: Eletty ja kerrottu kertomus - Sosiologia vol. 41, 4/2004: ss. 297-309.

— 2006: Kerronnallinen tutkimus. - Matti Hyvärinen [online]. < www.hyvarinen. info $>$ [Viitattu 8.3.2007.]

LEFEBVRE, HENRI 1994: The Production of Space. Oxford, UK and Cambridge, USA: Blackwell Publishers. [1974]

LENNQVIST, ERIC 1885: Historisk Afhandling om Åbo Slott. - Bidrag till kännedomen af vairt land, samlade och utgifna af K. G. Leinberg, Professor. Vol. 1. Jyväskylä: J. Länkeläs förlag.

LEPOKORPI, NINA 2000: Juhana-herttuan hovissa. - Puhakka, Martti (toim.), Turun linna. Turku: Turun maakuntamuseo.

LILLJA, J. W. 1865: Åbohus den 28. februari. - Abo Underrättelser 28.2.1865

Museovirasto restauroi 2004. Museoviraston rakennushistorian osaston raportteja 12. [Sahlberg, Marja (toim.)] Helsinki: Museovirasto.

POTTER, JONATHAN 2000: Representing Reality. Discourse, Rhetoric and Social Construction. London: Sage. [1996] 
PUHAKKA, MATTI \& GRÖNROS, JARMO 1995: Turun linna. Päälinnan opaskirja. Turku: Turun maakuntamuseo.

RICOEUR, PAUL 1990: Time and Narrative. Vol 1. Chicago: The University of Chicago Press. [1983]

- 1991: Mimesis and Representation. - Valdés, Mario J., A Ricoeur Reader: Reflection and Imagination. Toronto: University of Toronto Press.

- 2005: Mimesis, viittaus ja uudelleenhahmottuminen. - Tontti, Jarkko (toim.), Tulkinnasta toiseen. Esseitä hermeneutiikasta. Tampere: Vastapaino.

SAARIKANGAS, KIRSI 2002: Merkityksellinen tila: lähiöasuminen arkkitehtuurin, asukkaiden, menneen ja nykyisen kohtaamisena. - Syrjämaa, Taina \& Tunturi, Janne (toim.), Eletty ja muistettu tila. Historiallinen arkisto 115. Helsinki: Suomalaisen Kirjallisuuden Seura.

SAHLBERG, IRJA 1957: Alexandra Fredriksson In memoriam. - Turun kaupungin historiallisen museon vuosijulkaisu 1956-1957. Turku: Turun sanomalehti ja kirjapaino osakeyhtiö.

TOPELIUS, Z. 2000: Turun linnan tonttu-ukko. VI painos. Vammalan kirjapaino Oy. [1849 Sagor.]

VALTIOPÄIVÄASIAKIRJAT 1882: Asiakirjat valtiopäiviltä Helsingissä vnonna 1882. Viides osa. "Yleisen valitusvaliokunnan mietintö, n:o 9, kolmen Porvarissäädyssä tehdyn ehdotuksen johdosta, jotka koskevat Turun, Wiipurin ja Käkisalmen linnojen korjausta" ja "Suomenmaan Säätyjen alamainen anomus maan muinaislinnojen korjauksesta" Säät. Anom. - Anomusmiet. N:o 9. Helsinki: J. Simeliuksen perillisten kirjapaino, 1883.

FM Petja Aarnipuu on folkloristiikan jatko-opiskelija Helsingin yliopistossa ja viimeistelee väitöskirjaansa Turun linnasta. 